\title{
Demonstrating the Biobriquettes Production using Variations in Particle Size and Binder Concentration using Audio-Visual to Vocational Students
}

\author{
Asep Bayu Dani Nandiyanto ${ }^{1, *}$, Rama Tiyana ${ }^{2}$, Dewi Nur Azizah', Siti Nur Hofifah ${ }^{3}$ \\ ${ }^{1}$ Departemen Kimia, Universitas Pendidikan Indonesia, Jl. Setiabudi No. 229, Bandung, 40154, Indonesia \\ ${ }^{2}$ Program Studi Pendidikan Teknologi Agroindustri, Universitas Pendidikan Indonesia, Jl. Setiabudi No. 229, Bandung, \\ 40154, Indonesia \\ ${ }^{3}$ Departemen Biologi, Universitas Pendidikan Indonesia, Jl. Setiabudi No. 229, Bandung, 40154, Indonesia \\ ${ }^{1}$ nandiyanto@upi.edu \\ ${ }^{2}$ ramatiyana020@gmail.com
}

\begin{abstract}
The purpose of this study is to improve students' understanding of vegetable waste management through the production of biobriquette using audiovisual experimental demonstration. The study is conducted by conducting a pretest to assess student knowledge; teaching biobriquette using instructional video recordings and content explanations and finalizing video recordings based on the results of the first test analysis. Each step is thoroughly scrutinized with an assessment test. The experimental demonstration conducted by observing the biobriquettes production using peanut shells using variation in tapioca binder concentration $(10,20$, 3040 , and 50\%) and the peanut shell particle sizes (1184, 582 , and 310 micrometers). The teaching analysis shows that students understanding has improved significantly after giving treatment using the audio-visual experimental demonstration as the media improves students' comprehension, gives more information, and stimulates students' curiosity and interest in the subject matter. This research provides new knowledge on the need for educational media to illustrate audio-visual experiments to increase student comprehension.
\end{abstract}

Keywords: Audio-visual, Biobriquette, Peanut Shells, Particle Size, Vocational High School.

\section{Corresponding Author}

*Departemen Kimia, Universitas Pendidikan Indonesia, Jl. Setiabudi No. 229, Bandung, 40154, Indonesia

*nandiyanto@upi.edu

\section{Introduction}

Audiovisual media is a medium featuring sound and image components. Audio-visual technology is used to deliver information utilizing mechanical and electronic devices to display audiovisual messages. Audiovisual teaching highlights the learning value of actual knowledge, not just words-based learning. The advantages of audiovisual media in the form of video are that they can increase student interest and motivation, clarify abstract concepts, and provide a more realistic picture as well as explain a process and skill (Utami, 2013). In line with the literature (Yusup, Aimi, and Pertiwi, 2016), the effective learning conducted using audiovisual media can attract students' attention. Research has also found that the use of audiovisuals is more effective than the traditional method of skill learning (Haryoko, 2012).

The use of audio-visual as a learning media for students is essential. This can improve the teaching system in vocational high schools emphasizes the principles of skills (Ana, 2020). In particular, the material evaluating processed vegetable waste (Setyaningrum, 2017). To date, the use of vegetable waste management is limited to its use as compost, craft materials, and other food ingredients for consumption (Sulastri and Rahmidar, 2016). However, there is only a limited study on vegetable waste management into energy resources, specifically renewable energy. One of the vegetable waste management processes into an energy resource is bio briquettes production. Biobriquette is an alternative energy substitute for fuel produced from underutilized organic or agricultural waste (biomass) (Martynis, Sundari, and Sari, 2012). In line with the literature on the production of biomass briquettes from a mixture of peanut shells and corncob, charcoal shows that briquettes are effectively used as a renewable alternative fuel source (Purnawarman, Nurchayati, and Padang, 2015) and that there is an increase in cognitive value ( $\mathrm{N}$-gain) for students which is marked by an increase in N -gain (Suryani, Farid, and Mayub, 2019).

The development of peat and seed cane biobriquettes using audiovisual as a source of learning, the level of comprehension is $93.33 \%$, which is very useful as a learning 
resource (Mariati, 2017). Therefore, this study aimed to determine the effect of teaching demonstration using audiovisual experiments to vocational school students regarding the making of peanut shell-based biobriquettes with variations in tapioca binder concentration and particle size. The research was conducted by assessing the level of students' understanding of the production of peanut shellbased biobriquettes through pretest and posttest evaluation after using audio-visual experimental demonstration media.

\section{Method}

\subsection{Making Biobriquttes}

\subsubsection{Preparation of Tools and Materials}

The tools used in this study are a knife, ruler, oven, thermometer, electrical furnace, alcohol thermometer, digital scale, stove, gauze, balance sheet, beaker glass, mesh sieve, saw-mill, and briquette molds, while the materials used are peanut shells waste, tapioca flour, and water.

\subsubsection{Biobrioquettes Production Process}

The briquette production conducts using the peanut shells waste taken from a farm in Garut, Indonesia. The peanut shells cut into two parts, then dries using an electrical furnace at a temperature of $80-120^{\circ} \mathrm{C}$ for an hour. Furthermore, charcoal or carbonization is conducted using an electrical furnace at a temperature of $250^{\circ} \mathrm{C}$ for two hours. Upon turning into charcoal, the charcoal is crushed using a saw-mill and sieved using a mesh sieve with a particle size of 1184,582 , and 310 micrometers to standardized the size. The peanut shell charcoal is mixed with tapioca flour at various concentrations of $10,20,30,40$, and $50 \%$, adding boiling water until the mixture becomes smooth. The molding made using a metal ring with a diameter of $3.50 \mathrm{~cm}$ and a height of $1 \mathrm{~cm}$. The dough is put into the mold with a pressure of $10.45 \mathrm{~N} / \mathrm{m}^{2}$. The calculation of pressure is carried out using the formula:

$F=m \times g$

$P=\frac{F}{A}$

After the briquettes are molded, the drying process is conducted inside the electrical furnace with temperature $<150^{\circ} \mathrm{C}$ until the weight of the briquette weight is constant (4-5 hours).

\subsection{Data Analysis}

Testing the characteristics of the biobriquette with variations in the size of the particles and the mixture is carried out to determine the quality of the briquettes produced. These tests include:

\section{i. Compressed Density}

Compressed Density (CD) is the biobriquette density after printing. The $\mathrm{CD}$ value is obtained by comparing the weight and volume of the newly minted briquettes.

\section{ii. Relaxed Density}

Relaxed Density (RD) is the density of biobriquette after drying. The RD value is obtained by comparing the weight and volume of briquettes that have been dried and achieving a constant weight.

iii. Relaxation Ratio

Relaxation Ratio (RR) is the ratio between CD and RD values. The $R R$ value is obtained by comparing the $C D$ and $\mathrm{RD}$ values.

iv. Percentage of Moisture Content

Percentage of Moisture Content (PMC) indicates the moisture of the biobriquette. The PMC value is obtained by comparing the weight of the briquettes that have just been molded and those that have been dried.

v. Percentage of Durability Index

Percentage of Durability Index (PDI) is the resistance of dry biobriquette PDI value obtained by calculating the percentage of briquette weight after and before the briquette is dropped from a certain height.

vi. Percentage of Water Resistance Index

Percentage of Water Resistance Index (PWRI) shows the ability of briquettes to withstand water absorption. PWRI value is obtained by calculating the percentage of briquettes that do not absorb water.

vii. Specific Fuel Consumption.

Specific Fuel Consumption (SFC) shows the ratio of the mass of the biobriquette burned to the amount of water boiled.

\subsection{Teaching Method}

The subject of this study is 15 grade twelve vocational students of Agribusiness Program aged 18-19 years at one of the vocational high schools in Bandung Regency, Indonesia with 3 male respondents and 12 female respondents. The test is conducted in three stages and each stage is evaluated using direct observation (by assessment).

1) In the first stage, students are given the pretest questions to find out the students' knowledge of the briquettes that could have been collected.

2) In the second stage, students obtain teaching material on making peanut shell briquettes with variations in binder concentration and particle size through video learning media. A theoretical description of the biobriquette, the briquettes types for biobriquettes production, and the analysis added to the video. The students then are given the first posttest at the end of the experimental demonstration. The results of the first posttest analyzed to enhance video recording.

3) The third stage, finalizing the video recording. After conducting the analysis based on the first posttest result, the recording is improved to enhance students' test results. Then, students are given teaching materials about producing briquettes using peanut shells again.

4) Students can review the lesson themselves and learn extensively about the material presented. During the learning process, students are asked to carefully concentrate and observe the biobriquettes production process and its analysis. At the 
end of the experimental demonstration, the students are given a second posttest.

The pretest and posttest questions are the true-false question. The pretest and posttest questions given are described as follows:

1) Biobriquette is briquette made from biomass.

2) Biomass is often translated as bioresource or resources obtained from fossils.

3) The most commonly used briquettes are coal briquettes, charcoal briquettes, peat briquettes, and biomass briquettes.

4) Briquettes can be used repeatedly as an alternative fuel

5) Biomass carbon briquettes are briquettes made from biomass which is first turned into carbon and then turned into briquettes

6) Wet briquettes are briquettes made from biomass which is dried and directly compacted at high pressure without going through the carbonization process.

7) The carbon raw material for briquettes is obtained from the carbonization process of agro-industrial waste. Then, briquettes are made by mixing carbonized raw materials with adhesive materials. The higher the carbonization temperature, the higher the moisture content in the briquette.

8) The carbon raw material for briquettes is obtained from the carbonization process of agro-industrial waste. Then, briquettes are made by mixing carbonized raw materials with adhesive materials. The carbonization process aims to reduce smoke formation.

9) Carbon raw material for briquettes is obtained from the carbonization process of agro-industrial waste. Then, briquettes are made by mixing carbonized raw materials with adhesive materials. Carbonization is the process of converting organic material into charcoal.

10) Carbon raw material for briquettes is obtained from the carbonization process of agro-industrial waste. Then, briquettes are made by mixing carbonized raw materials with adhesive materials. Comparison of the amount of raw material will affect the quality of the briquettes

11) The carbon raw material for briquettes is obtained from the carbonization process of agro-industrial waste. Then, briquettes are made by mixing carbonized raw materials with adhesive materials. The size of the carbon particles does not affect the quality of the briquettes

12) The carbon raw material for briquettes is obtained from the carbonization process of agro-industrial waste. Then, briquettes are made by mixing carbonized raw materials with adhesive materials. Application of adhesive is to attract water and form a soft briquette texture

13) Carbon raw material for briquettes is obtained from the carbonization process of agro-industrial waste. Then, briquettes are made by mixing carbonized raw materials with adhesive materials. The type and amount of binder/adhesive will affect the mechanical strength (brittleness)

14) Carbon raw material for briquettes is obtained from the carbonization process of agro-industrial waste. Then, briquettes are made by mixing carbonized raw materials with adhesive materials. The higher the burning rate of the briquettes, the worse the briquette quality will be.

15)Carbon raw material for briquettes is obtained from the carbonization process of agro-industrial waste. Then, briquettes are made by mixing carbonized raw materials with adhesive materials. One of the parameters in briquettes is the specific fuel consumption (SFC), where $\mathrm{SFC}$ is the number of briquettes used to produce energy. The higher the SFC, the better the quality of the briquette (more economical).

\subsubsection{Making Audio-Visual Media}

Indonesian Ministry of National Education established guidelines in the making of Audio-Visual media which include the following steps:

1) Making a title. The title in the Audio-Visual shall be decided based on basic knowledge, subject matter or learning experience following the curriculum.

2) Making a synopsis.

3) Making storyboards featuring pictures and columns including narrative interpretations of images.

4) Editing using software for editing.

5) Conducting assessments that aim to improve student learning outcomes.

The audio-visual media in this study is created using the application Wondershare Filmora and presented to students.

\subsubsection{Audio-Visual Evaluation}

Furthermore, the evaluation is carried out to determine the effectiveness of the learning video. Evaluation is conducted by giving pretest, posttest 1 , and posttest 2 to students.

Before starting the aforementioned stages, students' basic information including IQ points and the average value of Chemistry, Physics, and Biology subjects is obtained to support the research instrument. Data processing is performed using paired sample T-Test on the IBM 24 Statistical Product and Service Solution (SPSS) application.

\section{Results and Discussion}

\subsection{Density}

\subsubsection{Compressed Density (CD)}

The average $\mathrm{CD}$ scores obtained in this study varied from 1.113 to $1.340 \mathrm{~g} / \mathrm{cm}^{3}$. Based on Figure 1, the highest CD value is obtained at the concentration of tapioca flour binder of $30 \%$ with a particle size of 310 micrometers. While the lowest value is obtained at $10 \%$ tapioca binder concentration with a particle size of 582 micrometers. As the concentration of tapioca flour binder increases, the $\mathrm{CD}$ value of the biobriquette tends to increase. According to (Wahidin, 2013), the particle size affected the CD value, and the higher the particle size resulted in the higher the $\mathrm{CD}$ value. The results in the literature (Davies, 2014) also prove that the binder concentration is directly proportional to the compressed density value. 


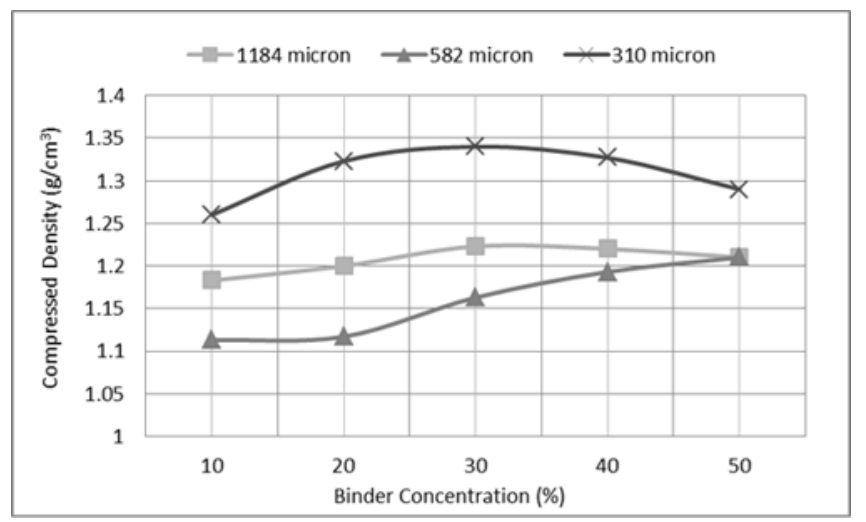

Fig. 1 Compressed Density Value of Peanut Shell Bio briquette

\subsubsection{Relaxed Density (RD)}

Relaxed density is the density of briquettes that is obtained after the briquettes are completely dry. The greater $\mathrm{RD}$ value results in the denser dry briquette. The average RD values obtained in this study varied from 0.689 to 0.876 $\mathrm{g} / \mathrm{cm}^{3}$. Based on Figure 2, the highest RD value is obtained at a binder concentration of $40 \%$ tapioca flour with a particle size of 1184 micrometers, while the lowest value is obtained at $10 \%$ tapioca binder concentration with a particle size of 582 micrometers. Along with the increase in the concentration of tapioca flour binder, the RD value of the biobriquette tends to increase. This is following the results of another research (Widiyandari, Setiabudi, Subagio, Haryanti, Siahaan, and Tjahjana, 2013), proving that the increases in the concentration of binders added led to the greater density value.

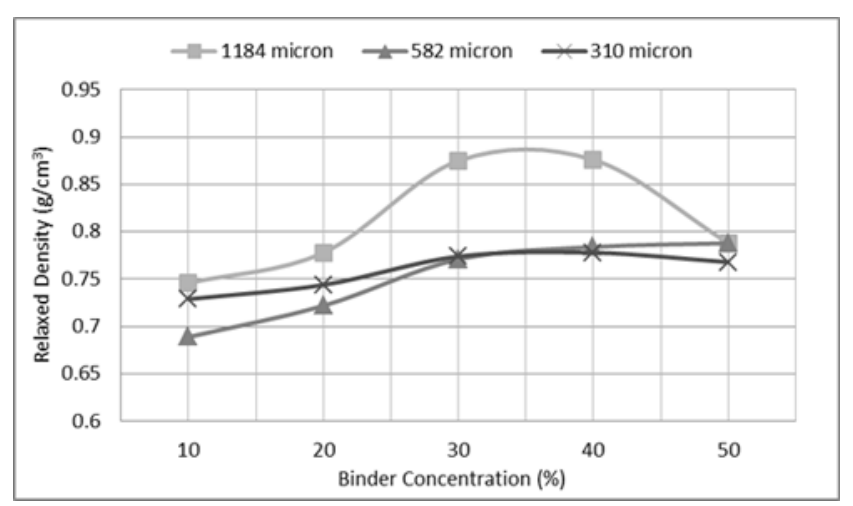

Fig. 2 Relaxed Density Value of Peanut Shell Biobriquettes

\subsubsection{Relaxation Ratio (RR)}

$\mathrm{RR}$ is the ratio of compressed density and relaxed density. Based on Figure 3, the highest RR value is obtained from briquettes with a binder composition of $20 \%$ tapioca flour with a particle size of 310 micrometers. The RR value indicates the stability of the briquette. The higher the particle size results in the higher relaxation ratio value and the higher the briquette stability (Aransiola, Oyewusi, Osumbitan, and Ogunjimi, 2019). In line with the literature (Olorunnisola, 2007), briquettes with a high $C D$ and $R R$ values will produce low RR values.

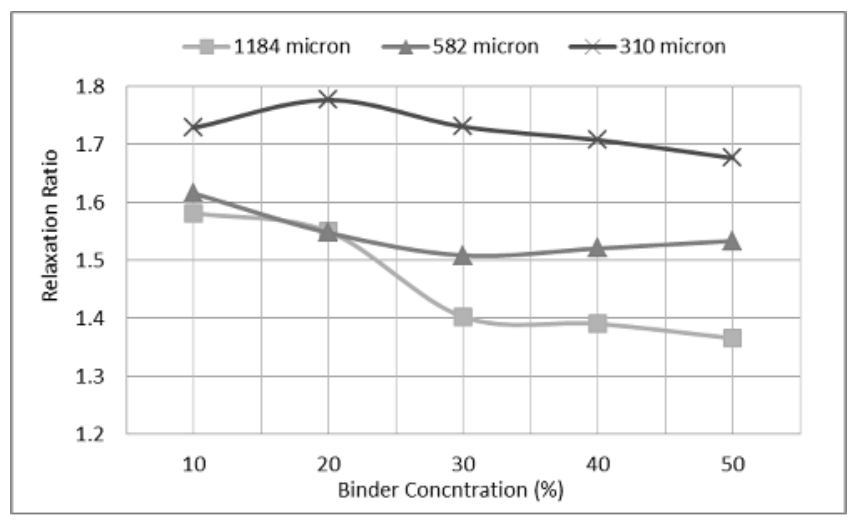

Fig. 3 The Relaxed Ratio Value of Peanut Shell Biobriquettes

\subsubsection{Percentage of Moisture Content (PMC)}

$\mathrm{PMC}$ is a presentation of briquette moisture content. The higher the PMC value allows the higher the briquette humidity (Figure 4). The value of PMC tends to decrease along with the increase in the concentration of tapioca flour binder. The higher the amount of adhesive used in making Biobriquettess, the smaller the water content in the Biobriquettes (Smith and Idrus, 2017). This is due to the use of a high amount of adhesive that will cause the number of particles of peanut shells to be wrapped. So, the adsorption of water vapor by the peanut shells particles is lower.

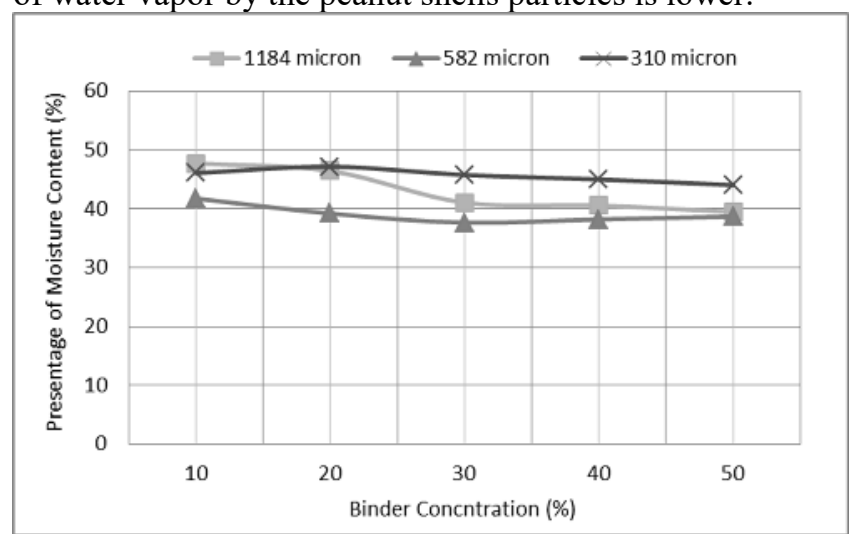

Fig. 4 Percentage Value Moisture Content of Peanut Skin Biobriquettes

\subsubsection{Percentage of Durability Index (PDI)}

PDI is an analysis to see the ability of briquettes to withstand damage due to collisions during the transportation and storage process. Based on Figure 5, the average PDI value obtained in this study varies from 43.10 to $99.84 \%$. The highest PDI value is obtained at the concentration of tapioca flour binder $50 \%$ with a particle size of 1184 micrometers, while the lowest value is obtained at $10 \%$ tapioca binder concentration with a particle size of 582 micrometers. The lower the concentration of binder added allows the higher the level of damage to the briquettes due to the impact. This is caused by the addition of the adhesive used that will increase the bond strength between the charcoal particles in the briquettes. The increases in the adhesive content allowed the stronger the bonds between the particles of the charcoal so the pressure strength is higher 
(Pane, Junary, and Herlina, 2015). The higher the percentage of durability index resulted the better a briquette.

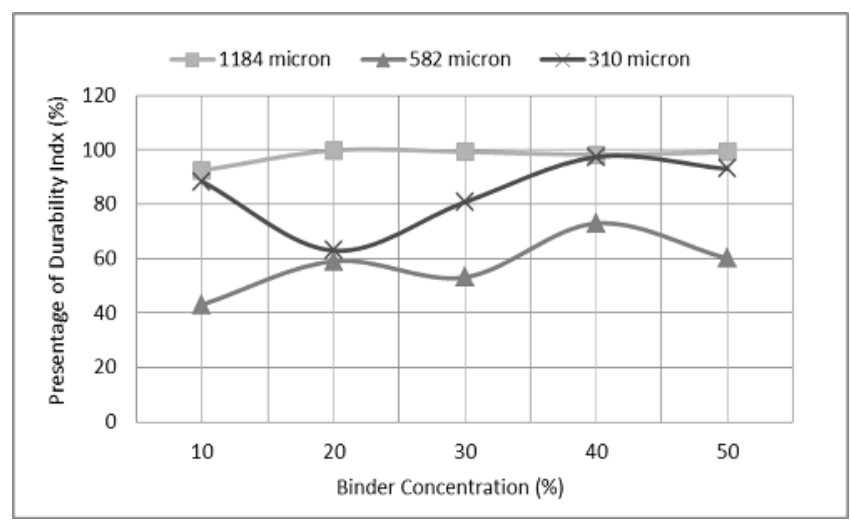

Fig. 5 Percentage of Durability Index Value of Peanut Shell Biobriquettes

\subsubsection{Percentage of Water Resistance Index (PWRI)}

PWRI is an analysis that shows the percentage of water content absorbed by the Biobriquettes. A good briquette is one that has a high PWRI value. Based on Figure 6, the biobriquette which has a high PWRI value is obtained at a binder concentration of $20 \%$ of tapioca flour with sizes of 310 micrometers. The greater the binder concentration results in the smaller the PWRI value generated in the briquette. The decreases in the PWRI value of the biobriquette are due to the addition of the adhesive concentration in strengthening the bonds between the briquette constituent molecules, thereby reducing the briquette's porosity (Martynis, Sundari, and Sari, 2012).

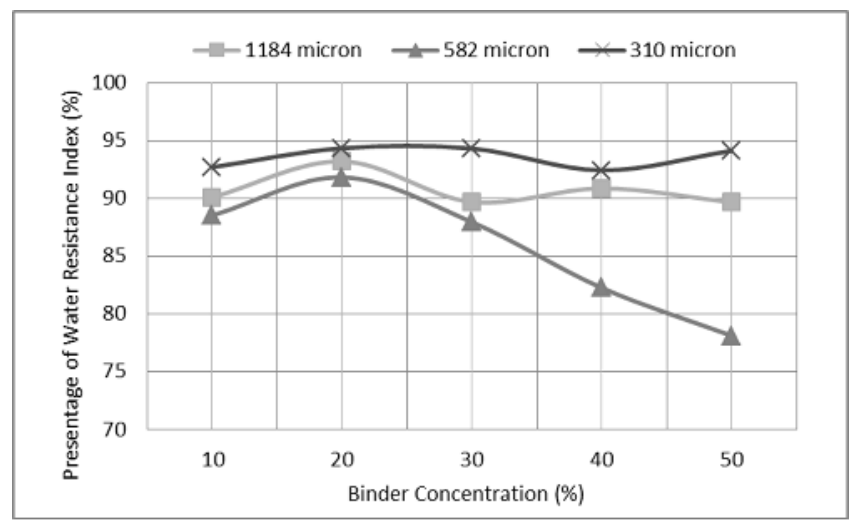

Fig. 6 Percentage of Water Resistance Index Value of Peanut Skin Biobriquette

\subsubsection{Burning rate $(B R)$}

$\mathrm{BR}$ is the average burnt period of the briquette. The better the briquette the higher the burning rate. Based on Figure 7 , the highest BR value is obtained at a binder concentration of $30 \%$ and the sizes of 1184 micrometers. The higher the binder concentration allows the BR value tends to increase. However, at a concentration of $40-50 \%$, the BR value drops sharply. This is due to the higher concentration of binders added that causes the biobriquette dense. Biobrickets that are too dense can affect the burning rate. This finding is in line with the study that states the burning rate is influenced by the density of the briquettes (Martynis, Sundari, and Sari, 2012). Besides, high-density briquettes would be difficult to burn. The addition of adhesive concentration will strengthen the bonds between the briquette constituent molecules, thereby reducing the porosity of the briquettes. Meanwhile, to maintain the flame during combustion requires sufficient oxygen. The more pores in the briquette provide more space for oxygen to enter so the combustion that occurs is better and provides a large burning rate.

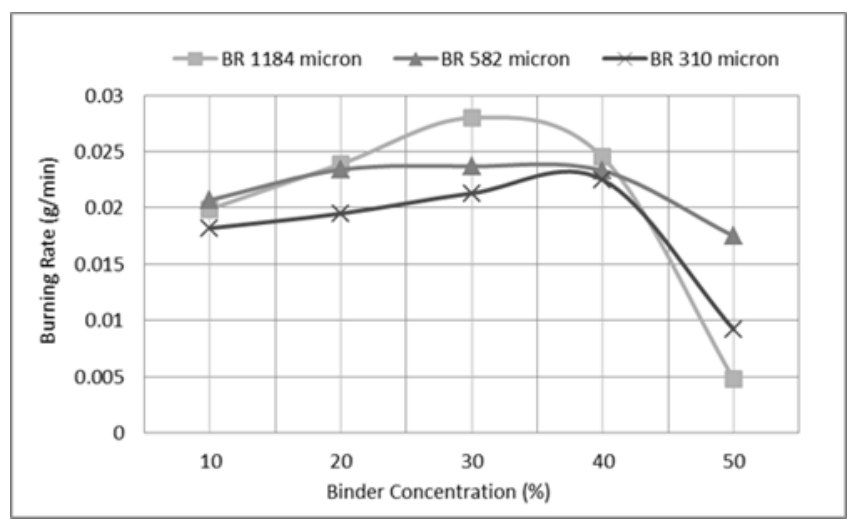

Fig. 7 Burning rate of Peanut Shell Biobriquettes

\subsubsection{Specific Fuel Consumption (SFC)}

SFC value is the ratio of the mass of the briquette burned to the amount of boiled water. Figure 8 shows that the biobriquette with the highest SFC value is obtained at a binder concentration of $20 \%$ of tapioca flour with sizes of 582 micrometers. This SFC value is directly proportional to the $\mathrm{BR}$ value. This can be seen in the curve that at a binder concentration of $10-20 \%$ allowed the SFC value and it continues to increase because the concentration of the added binder does not allow the briquettes to become too solid, which affects the burning rate of the briquettes. However, at the size of the tapioca binder concentration of $40-50 \%$, the SFC value is not directly proportional to the burning rate value because the number of particles after combustion is not completely dry. Indeed, it affects the final weight of the briquette, which has an impact on the SFC value.

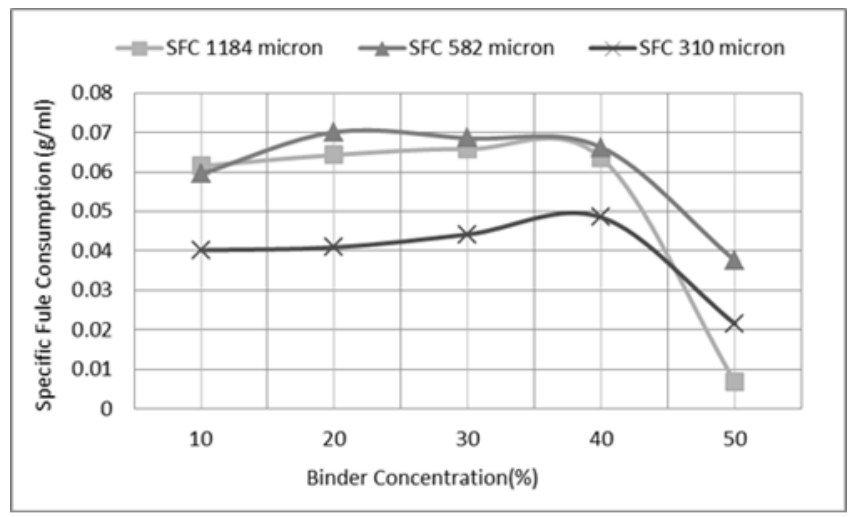

Fig. 8 SFC Value of Peanut Shell Biobriquettes 


\subsection{Teaching Results}

\subsubsection{Students' Demographic Data}

Before filling in the pretest and posttest questions, an analysis of students' interest in subjects related to processing vegetable waste is performed. Table 1 shows the student's interest in subjects that are essential in vocational schools. Three general subjects are taken as an assessment to determine the readiness of students in the learning process to process vegetable waste. Each student shows different characteristics of interest. This data is also used as a foundation for the recognition of intelligence and assessment of the effective learning methods (Hidayat, Rahmat, Fattah, Rochyadi, Nandiyanto, and Maryanti, 2020). Besides, students' IQ data are collected. Figure 9 illustrates the percentage of students' IQ scores using the David Wechsler scale. Students have a level of IQ intelligence that varies from slow learners (13\%), below average (47\%), and average (40\%) (Johnson, Langbehn, Long, Moser, Gutman, and Van der Plas, 2020).

Table 1. Student Interest in the Subject

\begin{tabular}{ccc}
\hline No & Subject & \multicolumn{1}{c}{ Score } \\
\hline 1 & Physics & $80.08 \%$ \\
\hline 2 & Chemistry & $81.20 \%$ \\
\hline 3 & Biology & $79.02 \%$ \\
\hline \multicolumn{3}{c}{ a Slow learning a vow $\square$ Normal }
\end{tabular}

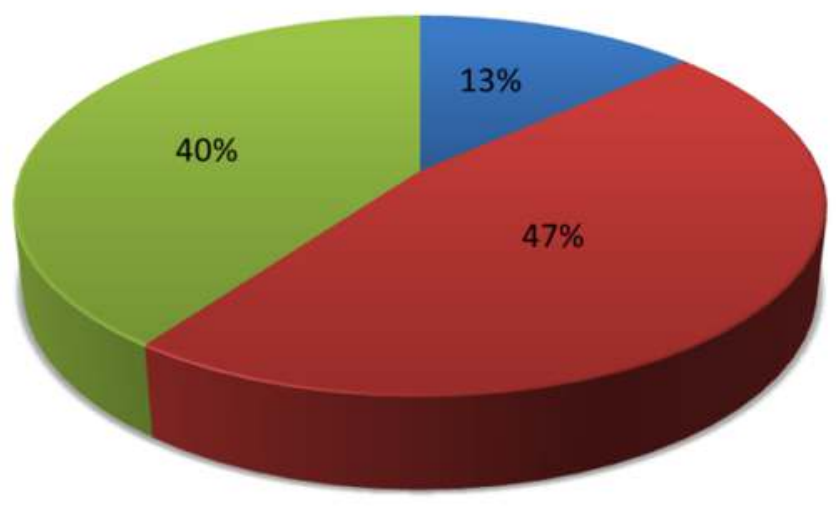

Fig. 9 Students IQ score

After obtaining data about students' interest in the subject and their IQ scores, pretest and posttest are given. The pretest results show that not all students understand about briquettes, but most students can answer the questions given. This can be prompted by students' lack of knowledge of briquettes that can be used as renewable energy. The posttest analysis shows an increase in students' understanding of briquettes. The posttest is conducted to measure the understanding of each student after the learning video is given (Nandiyanto, Asyahida, Danuwijaya, Abdullah, Amelia, Hudha, and Aziz, 2018). Table 2 presents the increase in student scores in all questions.
The use of audio-visual media to enhance the comprehension of low-intelligence students is very influential, as can be seen from the results of the pretest and posttest scores that have increased. Needless to say, the use of audio-visual media can improve students' comprehension, particularly those with low IQ. As found that the effective use of audiovisuals is used to improve students' intelligence, including students with intellectual disabilities (Permana, 2018). Besides, the use of media based on audio-visual experimental presentations enhances student comprehension, offers more knowledge and promotes students' curiosity and interest in the subject matter (Nandiyanto, Raziqi, Dallyono, and Sumardi, 2020).

On this study, questions to the students are given to determine their level of understanding during the learning process. The questions consisted of topics about the definition of biobriquettes, briquettes types, the production procedure, and the analysis. The results show that in general, the students' scores increase significantly. Only a few points have decreased compared to the first posttest, namely point number 12 and 15, but after correcting the video based on the first posttest analysis, there is an increase in the second posttest. The results of the assessment of the pretest and posttest questions are shown in Table 2.

Table 2. Students Score (\%) for Pretest Posttest using Experimental Demonstration Method

\begin{tabular}{|c|c|c|c|c|c|c|}
\hline \multirow{2}{*}{ No } & \multirow{2}{*}{ Pretest } & \multicolumn{2}{|c|}{ Posttest } & \multicolumn{3}{|c|}{ Acquisition (N-gain) } \\
\cline { 3 - 7 } & & $\mathbf{1}$ & $\mathbf{2}$ & $\begin{array}{c}\text { (Posttest } \\
\text { 1-Pretest) }\end{array}$ & $\begin{array}{c}\text { (Posttest } \\
\text { 2- } \\
\text { Pretest) }\end{array}$ & $\begin{array}{c}\text { (Posttest } \\
\text { 2-Postest } \\
\text { 1) }\end{array}$ \\
\hline 1. & 100.00 & 100.00 & 100.00 & 0.00 & 0.00 & 0.00 \\
\hline 2. & 26.67 & 26.67 & 66.67 & 0.00 & 40.00 & 40.00 \\
\hline 3. & 86.67 & 93.33 & 100.00 & 6.66 & 13.33 & 6.67 \\
\hline 4. & 13.33 & 20.00 & 80.00 & 6.67 & 66.67 & 60.00 \\
\hline 5. & 93.33 & 100.00 & 100.00 & 6.67 & 6.67 & 0.00 \\
\hline 6. & 20.00 & 33.33 & 46.67 & 13.33 & 26.67 & 13.34 \\
\hline 7. & 33.33 & 40.00 & 80.00 & 6.67 & 46.67 & 40.00 \\
\hline 8. & 86.67 & 93.33 & 100.00 & 6.66 & 13.33 & 6.67 \\
\hline 9. & 93.33 & 100.00 & 100.00 & 6.67 & 6.67 & 0.00 \\
\hline 10. & 86.67 & 86.67 & 100.00 & 0.00 & 13.33 & 13.33 \\
\hline 11. & 33.33 & 40.00 & 80.00 & 6.67 & 46.67 & 40.00 \\
\hline $12 *$ & 33.33 & 26.67 & 66.67 & $-6.66^{*}$ & 33.34 & 40.00 \\
\hline 13. & 93.33 & 93.33 & 100.00 & 0.00 & 6.67 & 6.67 \\
\hline 14. & 26.67 & 46.67 & 80.00 & 20.00 & 53.33 & 33.33 \\
\hline $15 *$ & 93.33 & 86.67 & 100.00 & $-6.66^{*}$ & 6.67 & 13.33 \\
\hline & & & & & & \\
\hline
\end{tabular}

Note: * There is a negative profit value

Based on the results of the analysis on the first pretest and posttest, the t-count is 0.027 . This is smaller than the $\mathrm{t}$ critical, namely 0.05 (t-count 0.027$)<(\mathrm{t}$-critical 0.05$)$. Thus, this test shows that the treatment, which uses a combination of experimental demonstration and media, significantly 
improves students' understanding of the topic of treating vegetable waste.

Based on the results of the analysis in the second pretest and posttest, the $\mathrm{t}$-count is 0.000 . This is smaller than the $\mathrm{t}$ critical, namely 0.05 ( $\mathrm{t}$-count 0.000$)<(\mathrm{t}$-critical 0.05$)$. Thus, this test shows that the treatment using a combination of experimental demonstrations and media significantly improves students' understanding of the topic of treating vegetable waste.

Based on the results of the analysis first posttest and the second posttest, the $\mathrm{t}$-count is 0.001 . This is smaller than the $\mathrm{t}$-critical, namely 0.05 (t-count 0.001$)<(\mathrm{t}$-critical 0.05 ). Thus, this test shows that the treatment using a combination of experimental demonstrations and media significantly improves students' understanding of the topic of treating vegetable waste.

After improving the video based on the results of the first posttest, the level of understanding of the students increased and some have decent scores. This is due to the video adjustment adapted to the number of students who responded inaccurately to specific questions. Thus, after seeing the second video, the student's scores increase.

Furthermore, students' comprehension of the topic increases as the video draws students' attention. The video does not only describe the content but also contains fascinating pictures and back-sound music that help student's understanding of the material. This finding is also in line with the study where the use of audio-visual media itself has increased student understanding since it can supplement students' basic experiences and describes a process accurately and repeatedly (Alfiani, 2020) and the improvement in cognitive value ( $\mathrm{N}$-gain) of students experiencing an increase in $\mathrm{N}$-gain using audio-visual media is also observed (Suryani, Farid, and Mayub, 2019).

\section{Conclusion}

Tapioca binder concentration and particle size have a significant effect on the characteristics of peanut shell biobriquettes. Meanwhile, based on the results of the teaching analysis using the paired sample T-Test on vocational high school students, it shows that students' understanding has increased significantly after being treated using an audio-visual demonstration experiment. The use of media also improves vocational high school students 'understanding and provides more information and stimulates students' curiosity and interest in the subject matter. This study produces new information about the need for instructional media for demonstration audio-visual experiments to improve student understanding.

\section{References}

Alfiani, A. (2020) Peningkatan Pemahaman Konsep Tentang Bagian Tumbuhan melalui Media Audio Visual pada Siswa Kelas IV SD Negeri 3 Menawan. In Social, Humanities, and
Educational Studies (SHEs): Conference Series, 3(3), 746751.

Ana, A. (2020). Trends in expert system development: A practicum content analysis in vocational education for over grow pandemic learning problems. Indonesian Journal of Science and Technology, 5(2), 71-85.

Aransiola, E. F., Oyewusi, T. F., Osunbitan, J. A., and Ogunjimi, L. A. O. (2019). Effect of binder type, binder concentration and compacting pressure on some physical properties of carbonized corncob briquette. Energy Reports, 5, 909-918.

Davies, R. M. (2014). Physical characteristics of some biomass briquettes. Journal of Advanced and Applied Sciences, 2 (2): 72-84

Haryoko, S. (2012). Efektivitas pemanfaatan media audiovisual sebagai alternatif optimalisasi model pembelajaran. Jurnal Edukasi Elektro, 5(1), 1-10

Hidayat, D. S., Rahmat, C., Fattah, N., Rochyadi, E., Nandiyanto, A., and Maryanti, R. (2020). Understanding Archimedes law: What the best teaching strategies for vocational high school students with hearing impairment. Journal of Technical Education and Training, 12(1), 229-237

Johnson, C., Langbehn, K. E., Long, J. D., Moser, D., Cross, S., Gutmann, L., and van der Plas, E. (2020). Encoding of facial expressions in individuals with adult-onset myotonic dystrophy type 1. Journal of Clinical and Experimental Neuropsychology, 42(9), 932-940.

Mariati, L. (2017). Pembuatan biobriket dari gambut dan ampas tebu sebagai sumber belajar materi ilmu kimia dan peranannya. Konfigurasi, Jurnal Pendidikan Kimia dan Terapan, 1(1), 113-120.

Martynis, M., Sundari, E., and Sari, E. (2012). Pembuatan biobriket dari limbah cangkang kakao. Jurnal Litbang Industri, 2(1), 35-41.

Nandiyanto, A. B. D., Asyahidda, F. N., Danuwijaya, A. A., Abdullah, A. G., Amelia, N., Hudha, M. N., and Aziz, M. (2018). Teaching "nanotechnology" for elementary students with deaf and hard of hearing. Journal of Engineering Science and Technology, 13(5), 1352-1363.

Nandiyanto, A. B. D., Raziqi, G. Y., Dallyono, R., and Sumardi, K. (2020). Experimental Demonstration for Enhancing Vocational Students' Comprehension on Heat Transfer through Conduction and Radiation of Light Bulb. Journal of Technical Education and Training, 12(3), 189-195.

Olorunnisola, A. (2007). Production of fuel briquettes from waste paper and coconut husk admixtures. Agricultural engineering international CIGR ejournal, 9 (6), 1-11.

Pane, J. P., Junary, E., and Herlina, N. (2015). Pengaruh konsentrasi perekat tepung tapioka dan penambahan kapur dalam pembuatan briket arang berbahan baku pelepah aren (arenga pinnata). Jurnal Teknik Kimia USU, 4(2), 32-38. 
Permana, C. (2018). Development of Audiovisual Animation Media of Learning Vocational Art Music For Mentally Disabled. Jurnal Penelitian Pendidikan Indonesia (JPPI). 4(2), 122-128

Purnawarman, P., Nurchayati, N., and Padang, Y. A. (2015). Pengaruh komposisi briket biomassa kulit kacang tanah dan arang tongkol jagung terhadap karakteristik briket. Dinamika Teknik Mesin, 5(2), 131-139.

Setianingrum, M. (2017). Penggunaan variasi media ajar terhadap 3 gaya belajar siswa dalam pembelajaran bahasa jepang. JAPANEDU: Jurnal Pendidikan dan Pengajaran Bahasa Jepang, 2(1), 1-8.

Smith, H., and Idrus, S. (2017). Pengaruh penggunaan perekat sagu dan tapioka terhadap karakteristik briket dari biomassa limbah penyulingan minyak kayu putih di Maluku. Majalah Biam, 13(2), 21-32.

Sulastri, A., and Rahmidar, L. (2016). Fabrication of biomembrane from banana stem for lead removal. Indonesian Journal of Science and Technology, 1(1), 115131

Suryani, E., Farid, M., and Mayub, A. (2019). Implementasi karakteristik nilai kalor briket campuran limbah kulit durian dan tempurung kelapa pada pembelajaran suhu dan kalor di SMPN 15 kota Bengkulu. PENDIPA Journal of Science Education, 3(3), 146-153.

Utami, K. (2013). Penggunaan media audio visual untuk meningkatkan pemahaman konsep siswa di sekolah dasar. Jurnal Penelitian Pendidikan Guru Sekolah Dasar, 1(2), 1-10.

Wahidin, N. A. (2013). Karakteristik biobriket kulit durian sebagai bahan bakar alternatif terbarukan. Jurnal Teknologi Industri Pertanian, 23(1), 70-76.

Widiyandari, H., Setiabudi, W., Subagio, A., Haryanti, S., Siahaan, P., and Tjahjana, H. (2013). Pengaruh penggunaan binder terhadap densitas dan kalor pembakaran briket dari limbah sagu. Indonesian Journal of Applied Physics, 3(02), 188-194.

Yusup, M., Aini, Q., and Pertiwi, K. D. (2016). Media audio visual menggunakan videoscribe sebagai penyajian informasi pembelajaran pada kelas sistem operasi. Technomedia Journal, 1(1), 126-138. 